Portland State University

PDXScholar

6-16-2021

\title{
Homeless Students' Barriers to Education: Before and After COVID-19
}

Linda M. Twidwell

Portland State University

Follow this and additional works at: https://pdxscholar.library.pdx.edu/honorstheses

Part of the Other Education Commons, and the Social Work Commons Let us know how access to this document benefits you.

\section{Recommended Citation}

Twidwell, Linda M., "Homeless Students' Barriers to Education: Before and After COVID-19" (2021). University Honors Theses. Paper 1030.

https://doi.org/10.15760/honors.1056

This Thesis is brought to you for free and open access. It has been accepted for inclusion in University Honors Theses by an authorized administrator of PDXScholar. Please contact us if we can make this document more accessible: pdxscholar@pdx.edu. 
Homeless Students' Barriers to Education: Before and After COVID-19

\author{
by
}

Linda Twidwell

\begin{abstract}
An undergraduate thesis submitted in partial fulfillment of the requirements for the degree of Bachelor of Arts

in

University Honors

and

Child, Youth, and Family Studies
\end{abstract}

\author{
Thesis Advisor \\ Dr. Miranda Mosier
}

Portland State University

2021 


\section{Abstract}

This thesis is an examination of the barriers to education homeless youth may be faced with both before and after the COVID-19 pandemic. Using past literature, this paper will focus on three main barriers homeless students may have faced before the pandemic. These are homeless students' lack of support needed to succeed, how federal policy shapes homeless students' opportunities and rights, and that the rate of children experiencing homelessness is rising, and little is being done about the fact. After discussing the literature before March 2020, this paper will examine the literature that has come out since the pandemic's beginning, and discuss how the barriers are similar, different, and how past literature can be used to make predictions about the pandemic's long term effects on homeless students' educational opportunities. Finally, this paper will offer potential solutions or recommendations for supporting youth experiencing homelessness in receiving an equitable education. 


\section{Introduction}

While progress has been made in recent years in reducing chronic homelessness among veterans and other single adults, the opposite is true for families (Grant et al., 2013). Family homelessness specifically emerged as a major social and public health problem in the United States during the 1980s. Families experiencing homelessness consist of at least one parent with a child under the age of 18 living without stable adequate housing (Mayberry et al., 2014). Young children are particularly vulnerable to the negative developmental impact of homelessness, and as shown in studies done in American shelters, the majority of school-age homeless children are faced with some kind of psychiatric, behavioral, or academic challenge (Grant et. al, 2013). Homelessness often has a devastating impact on children and youth's educational opportunities.

For this paper, the definition of a homeless student from the federal McKinney-Vento Homeless Assistance Act will be utilized. This law defines a homeless child as lacking a "fixed, regular, and adequate nighttime residence" during the school year"(National Center for Homeless Education, n.d.). Also included in this definition are students who are sharing the housing of others, are living in motels, hotels, trailer parks, or camping grounds due to the lack of alternative adequate accommodations. This definition applies to students living in shelters, those who are abandoned in hospitals, or are awaiting foster care placement. It also includes children who are living in settings such as cars, parks, public spaces, abandoned buildings, etc., and migratory children (National Center for Homeless Education, n.d.). It is important to recognize the 
limitations of this definition during the time of COVID-19 where students were and/or are still learning remotely, and homeless children may not have a stable daytime residence either. This may impact some homeless students from being able to attend their classes or completing schoolwork.

Children who are experiencing homelessness may not have stability or adequate support to succeed academically. Bureaucratic barriers homeless students may face include but are not limited to residency requirements, delays in transfer of school records, guardianship requirements, lack of transportation, and lack of immunization records (Sulkowski \& Joyce-Beaulieu, 2014). Many of these barriers have been created by the structure of the education system. These inequities and structural problems have existed for decades, but have been brought to the forefront in the past fourteen months due to the COVID-19 pandemic. COVID-19 has disrupted all aspects of life across the country, and has exposed pre-existing inequities in many areas, including education. For this thesis, I will review the barriers homeless youth faced in receiving an equitable education before the COVID-19 pandemic, the barriers that have been created and/or exacerbated by the pandemic, and draw on past research to predict long term effects of COVID-19 on homeless students, and offer potential strategies to mitigate the inequalities.

\section{Homeless Students Before COVID-19}

This section will examine the scholarship on homeless youth and their barriers to education completed before the COVID-19 pandemic. This scholarship has highlighted three main issues that this paper will focus on. These are homeless 
students' lack of support needed to succeed, how federal policy shapes homeless students' opportunities and rights, and that the rate of children experiencing homelessness is rising, and little is being done about the fact.

\section{Lack of Support}

The first issue is homeless students' lack of support needed to succeed, which comes from both institutions and individuals. Miller's (2011b) literature review noted that students experiencing homelessness need supportive people, places, structures, and collaboration from the community. Miller (2011b) used a network perspective to see the complex webs between all aspects of life. Houseless students need support from more than just the school in order to succeed in their academic performance and take care of their social and emotional wellbeing. Havlik et al. (2018) noted that homeless students often need support in meeting basic needs such as healthy food to eat, clean clothes to wear, and access to health care. In order to meet these needs, educators and school counselors can build systemic interventions that utilize the strengths of the family, school, and community (Bryan \& Henry, 2008).

Oftentimes, students experiencing homelessness are not able to receive these supports. One reason for this highlighted in the literature is that while homeless students face barriers to receiving the support they need, educators and counselors often face barriers that hinder their ability to provide the support needed. These barriers include the difficulty of identifying homeless students and being unprepared to provide the necessary support (Havlik et al., 2018). Certain families who would fit the definition of homeless that schools use would not self identify as homeless, which can 
end up having a negative impact on the student and family who may benefit from support from the school. Some families do not self identify as homeless because they do not fit the stereotypical image of a person sleeping on the street, but they would qualify for services because they fit in the definition described above. Lack of training or offering educators tools to help their students experiencing homelessness also can prohibit students from receiving the help they need. In order to effectively teach and support their homeless students, educators need to understand potential impacts of homelessness on learning (i.e. hunger, chronic absence, illness, economic exclusion), signs of homelessness to keep an eye out for, and ways to support their students while respecting their boundaries.

Homeless students may miss out on receiving helpful services because of their caregivers being unaware of the services available to them. Rafferty and Rollins (1989) looked into the impact on homeless students when they change schools, often due to change of shelter location. Rafferty and Rollins (1989) found that most parents were not aware that their children could be provided with transportation to school if they chose to stay, which highlights major miscommunications and problems at institutional levels within the school systems. This is significant because many barriers homeless students face come from the school itself and the lack of support, when the emphasis and blame is often placed on the family who is experiencing homelessness. This blame often comes from the individualistic ideals the United States holds as a society.

Homeless students are often overlooked by the education system and not provided with important social-emotional support (Sulkowski, 2016). Few homeless students receive mental health counseling or support at school, even though 
homelessness is a known risk factor for mental health problems (Sulwoski \& Michael, 2014). Some of the challenges that are common among homeless children are short attention span, separation anxiety, withdrawal, aggression, sleep disorders, poor social interaction, and delays in gross motor, speech, and language development (Yamaguchi et al., 1997). These challenges create great barriers for homeless students to receive an equitable education. All children living in poverty are at risk for poor academic achievement, and the risk is even higher among children who experience high residence mobility and homelessness (Herbers et al., 2012).

\section{Federal and State Policy Shapes Homeless Students' Opportunities}

The second issue highlighted throughout the pre-COVID literature on homeless students is how federal, state, and local policy shapes homeless students' opportunities and rights. At a local or state level, this could be a student's lack of address so they are unable to complete enrollment, or a student may not have access to healthcare, and cannot get their immunizations or may miss school due to illness. Different states have various requirements for children to attend school, which can become exclusionary for families experiencing homelessness. Bassuk et al. (2010) proposed a framework of policy changes that would include short term basic needs, ongoing supports, and lifelong supports. Examples of short term basic needs may be affordable housing or child care. An ongoing support may refer to education or health care, and a lifelong support is related to mental health, medical, or substance use. Ongoing supports are likely to change over time and the duration or intensity of these supports may wax and wane. Lifelong supports are more likely to be supports that are 
consistent throughout one's life.

The McKinney-Vento Homeless Assistance Act of 1987 was passed by President Reagan to provide federal money for homeless shelter programs (National Coalition for the Homeless, 2006). This act included assistance and expectations for schools as well. The act provided a definition of homelessness to which all schools were to adhere, it said school districts must provide students with transportation to and from school, it gave students opportunity to choose which schools they would attend, and it created an infrastructure to make sure there was implementation of the Act's elements on a state and local level throughout the country (Miller, 2011a). The McKinney-Vento Homeless Education Assistance Improvements Act of 2001 (MCKV) provided funds to local educational agencies, but there was a question as to whether or not this act actually improved students' academic achievement (Hendricks \& Barkley, 2012). Hendricks and Barkley (2012) found no difference between test scores of elementary students from local educational agencies in North Carolina who were affected by the act and those that did not receive funding. Biggar (2001) found that the original 1987 act upholds lofty principles, but contains crucial flaws in the act itself and in the enforcement of the act that greatly undermine its worth. One of the biggest flaws is effectively identifying students experiencing homelessness. Most local education agencies (LEAs) have existing employees also act as homeless liaisons, but are given limited support, thus they have a larger caseload and face significant challenges in identifying and supporting students, despite sincere intentions (Shephard et al., 2020). These federal acts are necessary and provide services homeless students should have already been getting, but they alone are not enough support for all homeless students 
academically.

\section{Homelessness Continues to be an Invisible Problem}

The third issue highlighted in the pre-COVID literature on homeless students is that the rate of children experiencing homelessness is rising, and little is being done about the fact. Child homelessness has reached levels unprecedented in the United States since the Great Depression (Tobin, 2014). Though the number of young homeless students is increasing, the students, teachers, school liaisons, and state coordinators report that student homelessness continues to be an invisible problem that is incredibly disruptive to the child (Ingram et al., 2017). Studies specifically describing the characteristics and needs of homeless children are fairly new, as these were sparse in the 80 's and 90 s, and there were no studies seeking to provide an estimate of the number of homeless children nationwide (Institute of Medicine, 1988).

Grant et al. (2013) completed a literature review of the work surrounding family homelessness that was largely done in the 1980s and ' 90 s. The goal of this review was to conclude whether or not the journals, government reports, and news stories were still relevant to the current state of homelessness as of 2013. In order to accomplish this, Grant et al. reviewed works from the previous 25 years and compared them to the current studies and statistics. The researchers found that while family homelessness increased over time, the older journals and reports were still relevant. This is largely because there has been less attention to the issue of child and family homelessness. The researchers reported that the works they reviewed were useful because there was not a sufficient amount of new research.There have been fewer research studies, 
government reports, broadcast stories, and less political attention to children and families in poverty.

\section{Homeless Students After COVID-19}

The rate of families experiencing homelessness was already growing before the pandemic, and the numbers are even higher now. Experts project that 1.5 million families will become homeless during this crisis (Coughlin et al., 2020). Coughlin et al. (2020) discuss the significant increase of homelessness as a result of COVID due to the rise in unemployment, increase in sickness, and new financial stressors. Because the number of homeless Americans is increasing, we can assume that the number of homeless students is as well.

This section will discuss the relevant literature that has come out since the beginning of the COVID-19 pandemic. The first school to shut down due to a coronavirus scare was in Washington on February 27, 2020 (The Coronavirus Spring, 2020). The first state to close down all schools was Ohio on March 12, 2020, and by March 25, 2020, all U.S. public schools were shut down (The Coronavirus Spring, 2020). All students were affected dramatically by the pandemic, but it is important to discover how the most vulnerable populations have been affected. This paper argues that the barriers homeless students faced before the pandemic and the barriers they face now in receiving an equitable education are largely the same, they just can no longer be ignored or swept to the side. Blundell et al. (2020) discuss many inequalities that the COVID-19 pandemic has brought to light and impacted. The main conclusion reached was that the pandemic will have long lasting effects on the inequalities that are 
already prevalent. The exacerbated inequalities in education must be addressed and there are potential solutions to the new problems and the ones that have already existed.

\section{Access to School in a Pandemic}

Since the shutdowns of schools in March of 2020, the majority of American schools have relied on distance learning. Distance learning is any learning that happens when the student and teacher are physically separated (Dietrich et al., 2020). In the past, distance learning was typically utilized by choice, when it would work better for the student to do so. However, due to the pandemic, students and teachers have been forced to adapt to distance learning, even in situations that create great accessibility barriers for certain students (Dietrich et al., 2020).

Previous research suggests that non-school factors are some of the primary sources of inequalities in educational outcomes. School is only one facet of children and youth's lives, and when there are challenges, traumas, and systemic inequalities happening in their lives outside of school it can be much harder to effectively learn. With distance learning during the pandemic being mostly online, accessibility barriers are being presented to students experiencing homelessness. Online learning typically requires computers, a reliable internet connection, and an environment suitable for getting classwork done (Van Lancker \& Parolin, 2020). Homeless students are more likely to struggle with completing their online assignments or being present for virtual meetings because of their precarious housing conditions (Van Lancker \& Parolin, 2020). 
Many schools are finding ways to accommodate students without internet or computers by providing laptops or printing hard copies of the lessons (Truong, 2020), but educators still believe this will widen the academic achievement gap between students from a higher socioeconomic status (SES) and students with a lower SES (Van Lancker \& Parolin, 2020). Kaden (2020) noted that the online curriculum needs to be carefully designed for the individual students to not deepen inequality, but it puts an extreme amount of work on teachers, and homeless students may not be able to get the distanced education they need and deserve.

\section{Non School Factors}

Homeless students' challenges during COVID-19 are not limited to the challenge of attendance and completion of school work. Many non school factors have been identified by past research that affect the learning opportunities of students, and the pandemic will likely exacerbate many of them. Berliner (2009) found that food insecurity, inadequate health care, and family stress all have the potential to limit students' learning opportunities and limit what schools alone can accomplish.

Food insecurity is increasing dramatically among Americans during the pandemic (Wolfson \& Leung, 2020). Gunderson et al. (2020) projected an increase of 17 million Americans facing food insecurity due to the pandemic in 2020. Professionals such as psychologists, nutritionists, and doctors agree that the evidence is strong suggesting that nutrition is linked with school behavior and achievement (Berliner, 2009). Howard (2011) found in a longitudinal analysis that food insecurity at home often results in significant developmental effects for children. 
Rosenthal et al. (2020) discuss the impact of COVID on homeless children living in temporary accommodation. A few of the main issues are the children's probable inability to self-isolate, adhere to social distancing, and challenges in receiving healthcare. These barriers are not directly related to school, but these conditions homeless students are experiencing may affect their ability to attend school and/or effectively learn. Homeless students may not have adequate health care, which could cause great problems if they or their family were to contract the virus, which could cause great family stress, which is another risk factor. Homeless students often are faced with great challenges outside of school, which can affect their ability to receive an equitable education. COVID-19 and its effects have likely exacerbated many of these challenges for homeless students.

\section{Comparing Barriers Before and After COVID-19}

This section aims to compare and contrast the previous barriers identified before and after the COVID-19 pandemic. These barriers include lack of support, how federal policy shapes homeless students' opportunities, the invisibility of homelessness in schools, access to school, and non school factors that influence homeless students' education. Many of the obstacles homeless students faced before the pandemic are still present but may look different now in a post COVID-19 time. The barriers many homeless students face in receiving an equitable education have stayed consistent since the beginning of the pandemic, but most have been exacerbated by the state of the world and put further stress onto these students.

Access to school continues to be an ongoing barrier to homeless students 
receiving an equitable education. Before the pandemic, many homeless students faced challenges being able to enroll and physically attend school. Examples that could have kept a homeless student from having access to school were transportation, having school supplies, residency requirements, delays in transfer of school records, guardianship requirements, lack of transportation, and lack of immunization records (Sulkowski \& Joyce-Beaulieu, 2014). Access to school looks a bit different in a distanced learning environment, but it continues to be a great barrier for students experiencing homelessness. As discussed in previous sections, homeless students may face challenges accessing their schooling due to lack of computers, reliable internet connection, and environment suitable for getting classwork done (Van Lancker \& Parolin, 2020).

Non School factors are another major factor in homeless youth's educational opportunities both before and after COVID-19. The non school factors now may be exacerbated by or created by the virus. COVID-19 itself has become a non school factor that affects students and their families greatly. The Centers for Disease Control and Prevention (CDC) recommends many preventative measures against COVID-19 that people experiencing homelessness may have limited access to such as frequent hand washing, avoiding high touch surfaces, self isolation, and fast access to medical care (Centers for Disease Control and Prevention, 2021). People experiencing homelessness may also be at a greater risk overall for illness (Centers for Disease Control and Prevention, 2021)

Another challenge that is consistent across time is the identification of students experiencing homelessness. In 2019, across 1,732 local education agencies in New 
Jersey, New Mexico, and New York, a randomized controlled trial of increased email communication between homeless liaisons and the school teachers was conducted to increase the identification of homeless students. The liaisons were sent lists of behaviors to look for that could indicate a student was experiencing homelessness, and they would communicate that with the teachers. The result was more than 3,000 additional homeless students were identified with a low-cost, low-intensity, behavioral intervention (Shephard, Hall, \& Lamberton, 2020).

There are many reasons why students who are homeless may not be identified as such by their school. Some students do not want to divulge the fact that they are experiencing homelessness out of self protection from stigmatization by peers, unwanted attention from staff, and possible intervention by social services (Ingram et al., 2017). Some families who are homeless do not want schools to know of their situation because of the fear of losing custody of their children (National Center for Homeless Education). Some families also may not know that they fit the definition of homelessness outlined by the Mckinney-Vento Homeless Assistance Act, and even school personnel may not always have a thorough enough understanding of the definition so some students are not identified as homeless (National Center for Homeless Education, n.d.). With the number of homeless families rising due to the pandemic, the challenge of identifying homeless students is increasing. The National Education Association is reporting that in the 2020-21 school year, schools have identified about 420,000 fewer homeless children and youth (Walker, 2020). Public schools were under-identifying homelessness before the pandemic, and now homeless students are becoming even more invisible to the educational system. 


\section{What past research can teach us about long term effects}

Educators believe that the effects of the pandemic and distance learning will widen the achievement gap between students from higher socioeconomic backgrounds and those from lower socioeconomic backgrounds (Van Lancker \& Parolin, 2020). The previous sections of this paper discussed the barriers to education many homeless students have been facing, and this section will predict long term effects on students facing homelessness.

\section{The Summer Slide}

The summer slide is a phenomenon first comprehensively studied in 1996 which refers to kids losing significant knowledge in reading and math over summer break (Austrew, 2019). If three months of not being in school causes significant widening of the achievement gap during summer, many educators have great concern about what the year of distance learning will do. Researchers have found that there is a large variation in summer learning among students, and that gaps between students of differing socioeconomic status widen (Atteberry \& McEachin 2020). Homeless students are already vulnerable to the summer slide, and many educators believe that the pandemic will severely widen the achievement gaps.

\section{Chronic Absenteeism}

Past research has shown the negative relationship between absenteeism and student outcomes becomes more intense the more school days that a student misses 
(Sugrue et al., 2016). Homeless youth and those who are forced to move or relocate (i.e. from foreclosure, eviction or other challenges) are at risk for higher absences (Henderson et al., 2014) and falling further behind in school. The information about the effects of chronic absenteeism is relevant to schooling in a post pandemic context because it reinforces the necessity of providing support to children who are the least prepared and especially to those at risk of becoming disengaged and eventually dropping out. Reduced learning time during the pandemic has most likely impeded student learning greatly.

\section{Homeschooling}

Research on homeschooling shows that it works well for students for whom intentional, personalized, and sufficient resources are available (Cheng \& Donnelly, 2019). The crisis-induced delivery of homeschooling without time for planning around children's learning styles and circumstances means that many homeless children doing distance learning during the pandemic are not able to replicate the model of homeschooling that would work for them which means they are not receiving the associated benefits. Teachers are working to provide education to all their students, but are ultimately being overwhelmed and overworked by this task (Dietrich et al., 2020). Because homeless students also may not have access to consistent internet or the technological resources required, remote education is impeding their ability to learn effectively. 


\section{Opportunity Gaps}

The United States has built an educational system that delivers disparate outcomes based on things like social class, minority status, and other student characteristics (Milner, 2012). Research has pointed out that there is more emphasis placed on achievement gaps, rather than opportunity gaps, where certain students cannot receive an equitable education because of their opportunities (Milner, 2012). The pandemic is exacerbating opportunity gaps associated with access to financial relief, health insurance, shelter, and food security.

\section{Potential Next Steps}

After discussing the current and potential effects of COVID-19 and homeless students' barriers to an equitable education, it is important to look ahead and discuss what can be done to support these students and their families. The first potential solution to many of the challenges homeless students are facing is allocating resources. Schools need resources so they can provide effective remote learning. These resources could include technical support, child care for teachers designing curriculum, and school materials for students. There will also need to be investments to help students make up for lost ground as many schools are now returning to in person learning. These could be things such as assessments to gauge where students are at with the course material, and anticipate the need for more personalized learning. The education system in some way may need rebuilding. One major issue highlighted by the pandemic has been the opportunity gap between different students depending on their background. Many homeless students have not had access to the same 
resources or education because of their living conditions, and schools will need to face that fact more than ever to ensure all children can receive an equitable education going forward.

\section{Conclusion}

Children and youth experiencing homelessness may face incredible barriers to receiving an equitable education. Before the COVID-19 pandemic these barriers included but were not limited to lack of academic and emotional support as well as support in meeting basic needs, bureaucratic barriers to enrolling and/or attending school, access to school, identification of students experiencing homelessness, and non school factors such as poverty, hunger, and stress. After the COVID-19 pandemic, the rate of homelessness in the United States is increasing due to the rise in unemployment, increase in sickness, and new financial stressors. This paper argues that the barriers to education are largely the same for homeless students after COVID--19, but can no longer be ignored. These barriers include access to school, non-school factors affecting students' ability to attend class and complete coursework, and the identification of homeless students. Looking into past research can assist educators, schools, and elected officials in developing strategies to support these students. This paper offers potential ways of moving forward by focusing on resources for schools and students, investing in making up for lost ground, and rebuilding of the educational system to provide support for students who need it. 


\section{References}

Atteberry, A. \& Mceachin, A. (2020). School's out: the role of summers in understanding achievement disparities. American Educational Research Journal. 58. 000283122093728. 10.3102/0002831220937285.

Austrew, A. (2019, June 5). How to prevent your kids from losing what they learned in school during summer vacation. Scholastic. https://www.scholastic.com/parents/books-and-reading/raise-a-reader-blog/sum mer-slide.html

Berliner, D. (2009). Poverty and potential: out-of-school factors and school success. National Education Policy Center. https://nepc.colorado.edu/publication/poverty-and-potential

Bassuk E., Volke K., \& Olivet, J. (2010). A framework for developing supports and services for families experiencing homelessness. The Open Health Services and Policy Journal, 3, 34-40.

Biggar, H. (2001). Homeless children and education: an evaluation of the Stewart B. McKinney homeless assistance act. Children and Youth Services Review, 23(12). 941-969. https://doi.org/10.1016/S0190-7409(01)00176-1.

Blundell, R., Costa Dias, M., Joyce, R., \& Xu, X. (2020), COVID-19 and inequalities*. Fiscal Studies, 41: 291-319. doi:10.1111/1475-5890.12232

Bryan, J., \& Henry, L. (2008). Strengths based partnerships: A school-family-community partnership approach to empowering students. Professional School Counseling, 12, 149-156.

The coronavirus Spring: The Historic closing of U.S. schools (a Timeline). (2020) Retrieved from https://www.edweek.org/leadership/the-coronavirus-spring-the-historic-closing-ofu-s-schools-a-timeline/2020/07

Centers for Disease Control and Prevention. (2021). Homelessness and COVID-19 
FAQs. Centers for Disease Control and Prevention.

https://www.cdc.gov/coronavirus/2019-ncov/community/homeless-shelters/faqs.h tml.

Cheng, A., \& Donnelly, M. 2019. New frontiers in research and practice on homeschooling." Peabody Journal of Education 94, no. 3: 259-262. https://doi.org/10.1080/0161956X.2019.1617576

Coughlin C.G., Sandel M., \& Stewart, A. M. Homelessness, children, and COVID-19: a looming crisis. Pediatrics. 2020; 146(2):e20201408

Dietrich, N., Kentheswaran, K., Ahmadi, A., Teychené, J., Bessière, Y., Alfenore, S., Laborie, S., et al. (2020) Attempts, successes, and failures of distance learning in the time of COVID-19. Journal of Chemical Education. 97(9), 2448-2457. DOI: 10.1021/acs.jchemed.0c00717

Grant, R., Gracy, D., Goldsmith, G., Shapiro, A., \& Redlener, I. E. (2013). Twenty-five years of child and family homelessness: where are we now? American Journal of Public Health, 103(S2). doi:10.2105/ajph.2013.301618

Gunderson, C., Hake, M., Dewey, A., \& Engelhard, E. (2020). Food insecurity during COVID-19. Applied Economic Perspectives and Policy. 00(00). 1-9. https://doi.org/10.1002/aepp.13100

Havlik S. A., Rowley, P., Puckett, J., Wilson, G., \& Neason, E. (2018). "Do whatever you can to try to support that kid": school counselors' experiences addressing student homelessness. Professional School Counseling. doi:10.5330/1096-2409-21.1.47

Henderson, T., Hill, C., \& Norton, K. (2014). The connection between missing school and health: a review of chronic absenteeism and student health in oregon. Upstream Public Health. http://schoolhealthteams.aap.org/uploads/ckeditor/files/Chronic-Absence-and-H ealth-Review-10 8 14-FINAL-REVISED.pdf

Hendricks, G. \& Barkley, W. (2012). Necessary, but not sufficient: The McKinney-Vento Act and academic achievement in North Carolina. Children \& Schools, 34(3).179-185, https://doi.org/10.1093/cs/cds007]

Herbers, J. E., Cutuli, J.J., Supkoff, L.M, et al. (2012). Early reading skills and 
academic achievement trajectories of students facing poverty, homelessness, and high residential mobility. Educational Researcher. 41(9):366-374. doi:10.3102/0013189X12445320

Ingram, E. S., Bridgeland, J. M., Reed, B., \& Atwell, M. (2017). Hidden in plain sight: homeless students in America's public schools. ERIC Document Reproduction Service No. ED 572753.

Institute of Medicine (US) Committee on Health Care for Homeless People. Homelessness, Health, and Human Needs. Washington (DC): National Academies Press (US); 1988. 1, Who Are the Homeless? Available from: https://www.ncbi.nlm.nih.gov/books/NBK218239/

Mayberry, L. S., Shinn, M., Benton, J. G., \& Wise, J. (2014). Families experiencing housing instability: the effects of housing programs on family routines and rituals. The American journal of orthopsychiatry, 84(1), 95-109. https://doi.org/10.1037/h0098946

Miller, P. (2011a). An examination of the McKinney-Vento Act and its influence on the homeless education situation. Educational Policy. 25(3). 424-450. doi:10.1177/0895904809351692

Miller, P. (2011b). A critical analysis of the research on student homelessness. Review of Educational Research, 81(3), 308-337.

Milner, R. H. (2012). Beyond a Test Score: Explaining Opportunity Gaps in Educational Practice. Journal of Black Studies, 43(6), 693-718. https://doi.org/10.1177/0021934712442539

National Center for Homeless Education. (n.d.) Identifying Children and Youth in Homeless Situations. https://files.eric.ed.gov/fulltext/ED574576.pdf

National Coalition for the Homeless. (2006). Mckinney-Vento act [Fact Sheet]. https://www.nationalhomeless.org/publications/facts/McKinney.pdf

Rafferty, Y., \& Rollins, N. (1989). Learning in limbo: The educational deprivation of homeless children (ERIC Risk and achievement trajectories 517 Doc. No. ED 312 363). Long Island City, NY: Advocates for Children. 
Rosenthal, D. M., Ucci, M., Heys, M., Hayward, A., \& Lakhanpaul, M. (2020). Impacts of COVID-19 on vulnerable children in temporary accommodation in the UK. The Lancet, 5(5), E241-E242. doi:https://doi.org/10.1016/S2468-2667(20)30080-3

Shephard, D., Hall, C., \& Lamberton, C. (2020). Identification of homeless students: an experimental evaluation of increased communication incorporating behavioral insights. Educational Researcher. doi:10.3102/0013189X20981067

Sulkowski M. L. \& Joyce-Beaulieu D. K. (2014). School-based service delivery for homeless students: relevant laws and overcoming access barriers. $\mathrm{Am} \mathrm{J}$ Orthopsychiatry, 84(6), 711-719. doi: 10.1037/ort0000033. PMID: 25545437.

Sulkowski, M. L. (2016). The student homelessness crisis and the role of school psychology: missed opportunities, room for improvement, and future directions. Psychology in the Schools, 53(7), 760-771. doi:10.1002/pits.21936

Sulkowski, M. L., \& Michael, K. (2014). Meeting the mental health needs of homeless students in schools: A multi-tiered system of support framework. Children and Youth Services Review. 44. 145-151 https://doi.org/10.1016/j.childyouth.2014.06.014.

Sugrue, E., Zuel, T., \& LaLiberte, T. (2016). The ecological context of chronic school absenteeism in the elementary grades. Children \& Schools, 38(3). 137-145. https://doi.org/10.1093/cs/cdw020

Tobin K. J. (2016). Homeless Students and academic achievement: evidence from a large urban area. Urban Education. 51(2):197-220. doi:10.1177/0042085914543116

Truong, D. (2020, March 18). As classes move online, what happens to students without internet or computers? NPR.

https://www.npr.org/local/305/2020/03/18/817691597/as-classes-move-online-w hat-happens-to-students-without-internet-or-computers

Van Lancker, W. \& Parolin, Z. (2020) COVID-19, school closures, and child poverty: a crisis in the making. The Lancet. 5(5) 243-245.

DOI:https://doi.org/10.1016/S2468-2667(20)30084-0DOI:https://doi.org/10.1016/ S2468-2667(20)3008 
HOMELESS STUDENTS: BEFORE \& AFTER COVID-19

Walker, T. (2020, November 30). Lost in the masked shuffle': Pandemic shields the real number of homeless students. National Education Association.

https://www.nea.org/advocating-for-change/new-from-nea/lost-masked-shuffle-p andemic-shields-real-number-homeless\#: : text=Contact $\% 20$ Us-',Lost $\% 20 \mathrm{in} \% 20$ the $\% 20$ Masked $\% 20$ Shuffle'\%3A\%20Pandemic $\% 20$ Shields $\% 20$ the $\% 20$ Real, $\% 2$ C\%22\%20said\%20one\%20district\%20liaison.

Wolfson, J. A. \& Leung C. W. (2020). Food insecurity and COVID-19: disparities in early effects for US adults. Nutrients. 12(6). doi: $\underline{10.3390 / n u 12061648}$

Yamaguchi, B. J., Strawser, S., \& Higgins, K. (1997). Children who are homeless: implications for educators. Intervention in School and Clinic. 33(2). 90-97. https://doi.org/10.1177/105345129703300204 